\title{
O 'Princípio Esperança' no Novo Cinema Português
}

\author{
CAROLIN O. FERREIRA \\ Universidade Federal de São Paulo
}

\begin{abstract}
Film scholars and historians mostly agree that Novo Cinema films made during the Portuguese dictatorship are fatalistic and not particularly political. However, using Ernst Bloch's "principle of hope," I argue in this essay that some of these films do in fact search for a hopeful future or change for Portuguese society. To prove my point I will first engage with the historical context and scholarly discussions of Novo Cinema before moving on to examine its key features films. Through a discussion of their main characters and aesthetics, I foreground the ways in which they call on their audience to question the status quo.
\end{abstract}

Keywords: Portuguese cinema; Ernst Bloch; Estado Novo; hope; politics and aesthetics

O 30 de maio de 1962, dia da estreia do filme Dom Roberto, produzido por meio da Cooperativa do Espectador e dirigido por Ernesto de Souza, é habitualmente referido como data inaugural de um capítulo diferente do cinema português: o do Novo Cinema. No entanto, esse "outro" cinema já era desejado, esperado e ansiado pelo menos desde 1960, quando o editor-chefe da revista Filme, Luis de Pina, dedicou no número 20 um dossiê ao "Novo Cinema português." Nessa "certidão de óbito" do velho cinema, como João Bénard da Costa apelida a publicação, Pina apostava toda sua esperança nos jovens diretores vindouros: 
. . . vivendo nos últimos anos de uma desconsoladora mediania, [o cinema português] precisa de sangue novo. Os que ficaram para trás, alimentando-se das próprias limitações e criando o mito da impossibilidade de fazer cinema em Portugal, parece já nada terem para dizer. (115)

Pina será o primeiro diretor da Cinemateca Portuguesa, inaugurada em 1958, e muitos dos nomes por ele citados, como Fernando Lopes e José Fonseca e Costa, encontraram caminhos para realizar um cinema considerado moderno e de autor. Vivenciar novas estéticas ou retornar para as da Vanguarda Histórica era um anseio compartilhado por cineastas, críticos ou cineclubistas que, desde os anos 50, vinham apontando, como expõe Fausto Cruchinho, "a necessidade do surgimento de um novo cinema português ou do ressurgimento e da regeneração do cinema em Portugal" (218).

A crise que vinha se arrastando desde o final dos anos 40 não escapava a ninguém, culminando no famoso ano zero em 1955, no qual não se produziu nenhum filme. Aprovada em 1948, a primeira "Lei de Protecção do Cinema Nacional" (lei no. 2027) levou à instauração do Fundo de Cinema, criado pelo órgão oficial do governo para o seu financiamento, o SNI (Secretariado Nacional da Informação), embora tivesse um efeito contrário e, devido às exigências nacionalistas do regime autoritário do Estado Novo, acabasse por paralisar totalmente a produção cinematográfica. Nesses anos, havia apenas tímidas tentativas de abandonar as matrizes dos gêneros clássicos do "velho cinema"- ou seja, as tradicionais comédias ou musicais à portuguesa, os melodramas e os filmes regionalistas - por meio de filmes de cariz neorrealista, associados, sobretudo, ao nome de Manuel Guimarães.

Como os cinemas de outras nações, que, a partir de meados dos anos 50, contestaram cada vez mais um certo tipo de cinema considerado convencional e anacrônico, chamado na França, por exemplo, de cinéma de papa, o cinema português participou do desejo de refletir sobre o imaginário nacional, e de renová-lo. Menciono apenas os mais notórios cinemas ditos modernos: a Nouvelle Vague, na França, o Cinema Novo, no Brasil, o Free British Cinema, no Reino Unido, ou o Neuer Deutscher Film, na Alemanha. Desinteressados em contar histórias dentro dos padrões de gênero estabelecidos, jovens diretores cinéfilos procuravam uma relação mais imediata com a realidade, 
Ferreira

demonstraram menos atenção aos encadeamentos racionais da história e mais preocupação com a mise-en-scène, elaborando assim uma estética aliada à política, bem como gerando formas de produção alternativas.

Comparado com as outras nações mencionadas, a situação política e cultural portuguesa era muito particular e pouco promissora. Apesar da radicalização do discurso oposicionista ao Estado Novo durante os anos 50, por meio do General Humberto Delgado, a oposição perdeu as eleições presidenciais de 1958, provavelmente por fraude. Após uma tentativa de revolta militar em 1959, Delgado, que pedira exílio no Brasil e tentara um golpe militar em 1962, foi assassinado em 1965. Outra tentativa de golpe de Estado, chefiada pelo General Botelho Moniz, ministro da Defesa, fracassara em 1961. Assim, a Guerra Colonial na África não foi evitada e, devido à mobilização de um contingente enorme de soldados, não só cobrou muitas vidas, mas também afetou profundamente a nação entre as datas de 1961 e a Revolução dos Cravos, no 25 de Abril de 1974, dia no qual se encerraria o autoritarismo da ditadura e do seu império. Como consequência da situação econômica e política, a emigração para os países ricos da Europa se tornaria fenômeno de massa ao longo da década de 60. Esse famoso "votar com os pés" por mais de um milhão de pessoas teve efeitos sociais e culturais igualmente marcantes.

Não admira saber que censura e autocensura eram frequentes. Como glosa José Cardoso Pires, ambas não datam apenas do início da ditadura em 1926, mas tornaram-se uma realidade já desde os tempos do Santo Ofício:

Ao longo de gerações e gerações, através de monarquias e impérios; de inquisições, ditaduras: arrastando silêncios, arrastando exílios, uma lenta procissão de mártires desfilou por esse incalculável corpus de naufrágios que são os milhares de quilômetros de textos lançados às fogueiras e aos arquivos. (163)

Sob essa perspectiva, a expectativa compartilhada por Luis de Pina, cineastas, críticos e cineclubistas, ganha outros contornos. É preciso lembrar que estes últimos terão um papel importantíssimo no Novo Cinema, embora tenham sido proibidos de se encontrar a partir de 1959. Paulo Filipe Monteiro descreve a tentativa da ditadura de esmagar o movimento da seguinte forma: 
A resposta estatal não foi nada favorável. Em 1957, foi proibida a exibição livre do filme de formato reduzido. Em 1958, realizou-se, em Santarém, o último dos encontros nacionais dos cineclubes; o de 1959 foi proibido. $\mathrm{O}$ ataque movido pelo Estado Novo, ataque que se estendeu das barreiras à contratação de filmes à censura e à própria intervenção policial, veio cercear drasticamente o movimento dos cineclubes, cujo apogeu, registado nos anos quarenta e cinquenta, não pôde assim prolongar-se na década seguinte. (321)

A postura dos intelectuais portugueses que ousaram pensar um novo cinema português demonstra que a esperança é uma característica do ser humano que lhe permite superar e transcender o real, como sugeriu Ernst Bloch em Princípio esperança (escrito entre 1938 e 1947 e publicado quase na mesma altura do encontro de cineclubistas, entre 1954 e 1959). Procurando desenvolver uma perspectiva metafísica para a teoria marxista, que se encontrava restrita à mudança da condição institucional-econômica, a obra de Bloch assumiu uma forma enciclopédica ao oferecer respostas complexas a perguntas tão simples quanto fundamentais como "Quem somos?" "De onde viemos?" "Aonde vamos?" Bloch considerava tais perguntas imprescindíveis, sobretudo após a Segunda Guerra Mundial e o Holocausto. São elas que abrem o livro junto com outra interrogação: "O que nos espera?" Já no primeiro parágrafo, Bloch apresenta uma resposta-síntese a suas inquietações: após uma fase em que se procurava aprender o medo, "esta arte de temer que era dominada de forma assustadora," ou seja, após a experiência das ditaduras totalitárias, tornou-se necessário "aprender a esperança," pois "o ato de esperar não resigna: ele é apaixonado pelo êxito em lugar do fracasso" (13).

Reaprender a capacidade de desejar, esperar e ansiar não significa, contudo, abandonar-se a projetos utópicos irreais. Antonio Rufino Vieira ressalta que o livro blochiano procurava apontar a viabilidade dos projetos para o futuro:

O Princípio esperança é um desafio para a necessidade de uma recuperação do sentido positivo da utopia, passando desde as denúncias dos utopistas do Renascimento até a prática político-social dos socialistas utópicos. . . . Assim, a utopia se torna viável à medida que possui o explícito desejo de ser realizada coletivamente. (2) 
Enquanto o projeto do Novo Cinema português poderia ser associado ao "Princípio esperança" de Bloch, tanto dentro de seus contornos metafísicos como fora deles, os filmes desse cinema raramente são associados a uma visão otimista, no sentido de um olhar esperançoso que busque uma sociedade livre e democrática. De fato, havia pouca possibilidade de contato com as novas e as velhas vanguardas cinematográficas por parte do público e costuma dizer-se que os espectadores, além de não habituados a linguagens cinematográficas diferentes, não aderiram aos filmes do Novo Cinema porque lhes pareciam fatalistas, herméticos e elitistas.

Em sua análise das publicações da década dos anos 50, João Bénard da Costa considera que a batalha contra o velho cinema foi ganha, mas que a batalha em favor de filmes novos foi perdida: "Até porque essa batalha contra tivera motivações políticas claras (atacar um cinema que já nada reflectia da realidade do país) e a batalha pró as não tinha, pois nenhum dos realizadores ou obras citados denunciava - ou podia denunciar, por óbvias razões censóriasessa mesma realidade" (126). O autor expressa, portanto, a opinião que se tornou lugar comum de que o Novo Cinema português inovava na sua estética, mas comprometia-se politicamente por seu estigma da convivência com o Estado Novo. Paulo Filipe Monteiro cita Costa extensamente e resume na mesma linha:

Ou seja, assim como antes do 25 de Abril o poder político cedera o poder a esses cineastas, sabendo que, ao contrário dos cineclubistas ou dos neo-realistas, eles pouco mobilizariam o grande público, e, mesmo que o fizessem, essa mobilização não giraria em torno de temas políticos, assim mais tarde, quando se defende um modelo populista, de reencontro com o grande público em torno do entretenimento, esses cineastas foram afastados. (338)

Conclui-se que os filmes não acabaram convencendo ninguém e que lhes faltava convicção política: "Até porque qualquer destas obras-aparentemente 'formalistas' e aparentemente 'idealistas'—não era de molde a despertar fervores ideológicos e a esquerda tradicional desconfiou tanto delas como a direita. O vanguardismo estético não tinha qualquer contrapartida em vanguardismos ideológicos" (Monteiro 338). 
O que seria vanguardismo ideológico? Aprender a esperar não poderia ser entendido como postura vanguardista? Gostaria de utilizar neste texto as ideias acerca do "Princípio esperança" de Bloch como ponto de partida para perguntar se os filmes do Novo Cinema português eram de fato marcados pelo aprendizado do medo, pelo contexto da repressão política e pela inovação estética sem "efeito," ou se podemos encontrar neles também a tentativa de aprender a esperança, partindo do princípio de que estética se relaciona sempre à política. Em outras palavras, questiona-se aqui se os filmes apresentam formulações estéticas capazes de invocar um futuro melhor e, quando o fazem, discute-se a maneira. Para contextualizar minha análise, retomarei brevemente e ampliarei a discussão acerca da periodização usual do Cinema Novo. Em seguida, apresentarei uma panorâmica das produções do Cinema Novo. Concentrar-me-ei nos filmes de ficção, seus protagonistas e seus possíveis horizontes de esperança.

\section{Alguns aspectos históricos do Novo Cinema português}

O Novo Cinema português é normalmente dividido em duas fases (Pina 143). A primeira abrange os filmes realizados entre 1963 e 1966 pela Produções Cunha Telles, enquanto a segunda compreende os filmes produzidos entre 1971 e 1975 pelo CPC (Centro Português de Cinema), subvencionados pela mais importante instituição cultural privada portuguesa, a Fundação Gulbenkian. Criada pelo diretor homônimo que investiu sua fortuna pessoal, a Produções Cunha Telles produziu dez filmes com uma equipe de diretores e atores que discutiam em conjunto as concepções da produção e os roteiros. A produtora foi responsável por alguns dos filmes mais importantes do Novo Cinema, como Os verdes anos (1963), de Paulo Rocha, Belarmino (1964), de Fernando Lopes, Domingo à tarde (1965), de António de Macedo, As ilhas encantadas, de Carlos Vilardebó (1965), e Mudar de vida, de Paulo Rocha (1966).

Os diretores desses filmes tinham realizado estágios ou estudos no estrangeiro, oferecidos ou pelo Fundo de Cinema ou pela Fundação Gulbenkian. Persuadido de que a aprendizagem fora de Portugal era a estratégia certa para reanimar o cinema nesse momento, o Fundo de Cinema investiu mais dinheiro em formação do que na realização de filmes até 1961. Esse fato é referido frequentemente como um dos paradoxos do Novo Cinema porque 
implicou o patrocínio da formação de jovens diretores por parte do Estado Novo. Os futuros cineastas foram estudar em escolas de cinema nos centros de inovação cinematográfica da época, isto é, em Paris, Roma ou Londres. Foi oferecida, pela primeira vez em Portugal, a oportunidade de fazer cinema por meio do Curso de Cinema, promovido em 1961 no Estúdio Universitário de Cinema Experimental da Mocidade Portuguesa, uma organização devota ao Estado Novo, que ofereceu 200 vagas.

Embora muitas das produções de Cunha Telles tivessem obtido também subsídios do Fundo de Cinema, a produtora foi obrigada a fechar em 1966 por causa de falência. ${ }^{1}$ Pouco familiarizado com estéticas experimentais ou anticonvencionais, e desgostoso das temáticas sociais, o público português de fato não aderiu ao Novo Cinema. A única exceção foi $O$ cerco, dirigido pelo próprio Cunha Telles, o maior sucesso de bilheteria do Novo Cinema, o que ocorreu apenas em 1969, quando a produtora já não existia.

Após a falência da Cunha Telles, os cineclubes vieram socorrer a situação. Esses clubes organizaram a Semana de Estudos sobre o Novo Cinema Português no Porto em 1967, subsidiada pela Fundação Gulbenkian, que apoiava diretamente a produção cinematográfica pela primeira vez, apesar de seu histórico de apoio às bolsas para estudar no exterior. Foi elaborado o documento $O$ ofício de cinema em Portugal durante a Semana, que foi apresentado depois à poderosa instituição com o objetivo de constituir uma sociedade cooperativa de novos cineastas com o apoio dela, o Centro Português de Cinema. A Fundação aceitou apoiar a sociedade coperativa durante um período experimental de três anos e assinou em 1968 essa decisão-ano em que o ditador António de Oliveira Salazar saiu após 35 anos do poder e a "Primavera marcelista" deu início a uma tímida abertura cultural. Incentivado por 19 diretores ligados ao Novo Cinema, o centro tinha autonomia plena, tanto em relação à seleção dos projetos de seus associados, quanto acerca da execução artística, e até mesmo com respeito à exploração comercial dos

\footnotetext{
${ }^{1}$ Fausto Cruchinho demonstra através de pesquisa em arquivo que "ao contrário do que diz a opinião generalizada, não são os 'maus' filmes e os 'maus' realizadores os únicos beneficiados pelo Fundo (ver anexo 3). Se exceptuarmos o período de Caetano de Carvalho (1969-1971), em que os filmes aprovados contemplam os 'velhos' realizadores (Henrique de Campos e Constantino Esteves) a par com os 'novos' (Cunha Telles e António de Macedo), são sobretudo os realizadores do 'cinema novo' os mais contemplados" (344).
} 
filmes, dado que a Gulbenkian recebia apenas uma cópia dos trabalhos realizados para uso interno em suas iniciativas culturais.

Os primeiros quatro filmes selecionados foram: O passado e o presente (1971), de Manoel de Oliveira, Pedro só (1971), de Alfredo Tropa, O recado (1971), de Fonseca e Costa, e Perdido por cem (1972), de António Pedro Vasconcelos, além de dois curtas-metragens, um de Paulo Rocha e um de João César Monteiro. Embora realizados com orçamentos pequenos, todos os filmes do CPC não renderam na bilheteira nem metade dos custos e obtiveram menos de 40 mil espectadores (Pina 1986). No entanto, houve reconhecimento crítico, tanto no estrangeiro na Semana de Nice, quanto na imprensa nacional por meio de referências positivas.

Além da Produções Cunha Telles e do CPC, quase todos os estudiosos que se debruçam sobre o início do Novo Cinema lembram três curtas-metragens como indicadores de um novo tipo de fazer documentários, filmes esses realizados em 1961 por Fernando Lopes, Baptista Rosa e Herlander Peyroteo e subsidiados pelo Fundo de Cinema. No entanto, há na historiografia do cinema português um par de indefinições, tanto em relação à determinação do início do Novo Cinema, quanto ao seu encerramento. Apesar da ruptura que a Revolução do 25 de Abril representou em 1974, filmes proibidos durante a ditadura estrearam nos anos a seguir, e o último filme do CPC só foi realizado em 1978.

Levando em consideração a vulnerabilidade desse tipo de periodização, é possível afirmar que ao longo de aproximadamente 17 anos (1961-1978) foram realizados filmes marcados pelo contexto sócio-histórico da ditadura e por uma procura estética e política específicas. Essas duas características podem justificar o fato de que sejam considerados filmes do Novo Cinema. Ainda devem ser incluídas na filmografia já referida algumas iniciativas que não estavam ligadas à produtora de Cunha Telles ou ao CPC, mas que se distinguem igualmente em termos de temática, estética e modo de produção daquele cinema considerado o "velho cinema," que se mantinha ativo ainda que de forma decadente (Matos-Cruz). Assim, podem ser contabilizados aproximadamente 46 filmes de longa-metragem, sendo 38 de ficção e apenas 8 documentários. Há ainda dois médias-metragens (um documentário e um filme de ficção) e seis curtas-metragens, os já mencionados documentários de 1961 e três curtas ficcionais do CPC que fizeram parte da formulação de respostas ao autoritarismo. 
Ferreira

\section{Os filmes}

Focando agora nos 30 longas-metragens de ficção realizados entre 1962 e 1978, gostaria de apontar algumas das preocupações mais marcantes. O panorama que traçarei apresenta uma tentativa de sistematização e comparação dos filmes do Novo Cinema português.

Não obstante a pluralidade de ideias e estilos, há uma inquietação comum a todos os longas-metragens de ficção aqui discutidos, nomeadamente o conflito

entre o velho e o novo ou a presença simultânea dos dois. Essa inquietação se traduz em diversas ordens e em locais variados, ora no meio urbano, ora no rural, com a particularidade de que o urbano se restringe exclusivamente a Lisboa, enquanto o rural abrange vilas de pescadores do norte ao sul de Portugal, bem como aldeias, de Trás-os-Montes até o Alentejo. O meio urbano é pano de fundo em 14 produções, ao passo que a vida rural aparece em 12 filmes. Apenas dois se deslocam aos territórios ultramarinos, outrora colonizadas por Portugal: um para a Índia (Goa) e um para Moçambique.

Ainda que os locais sejam bem diferentes, os conflitos que sucedem no meio urbano e no meio rural possuem diversos aspectos em comum. Não me refiro a duas forças antagônicas que se chocam abertamente quando digo conflitos. Muito pelo contrário, a maioria dos filmes é caracterizada pela ausência de um embate direto que afeta a ambas as partes envolvidas, como na tragédia grega. As crises surgem quase sempre de forma indireta ou deslocada, através de protagonistas — em sua grande maioria jovens—sem rumo ou com fortes dúvidas sobre o norte em suas vidas. Esses jovens encontram-se perante uma sociedade que percebem como fechada ou labiríntica, que os trata muitas vezes com desprezo ou com autoritarismo, e cujos valores e bens lhes parecem inacessíveis, estranhos ou ininteligíveis.

É possível apontar três tipos principais de crise ou conflito e que encontram-se muitas vezes interligados: 1) conflitos entre os protagonistas e a sociedade burguesa devido a diversos fatores, entre eles o desnível social e o autoritarismo do estado ou da família, que resulta de valores tradicionais de uma sociedade patriarcal ou do paternalismo da religião católica; 2) conflitos entre os gêneros devido ao chauvinismo que se desdobra em desrespeito com a mulher (dificultando a integração plena das mulheres na sociedade); e 3) 
conflitos gerados pela modernização seletiva do país, que busca sair do atraso, ao passo que restringe os benefícios a poucos).

Os dois tipos expressivos de produção, o da Produções Cunha Telles e o do CPC, acabaram dividindo o Novo Cinema em duas fases ao longo da sua manifestação. Sendo que essa periodização não deveria ser considerada a última palavra em relação ao Novo Cinema português, adotarei aqui uma abordagem ligeiramente diferente. Primeiro, discutirei os anos 1961-1966 através dos primeiros três filmes de longa-metragem (com financiamentos distintos, tanto do Fundo de Cinema quanto de uma cooperativa), incluindo Acto da primavera, de Manoel de Oliveira (1962), e por meio de algumas produções expressivas da Produções Cunha Telles. Depois, focarei apenas nos anos 1967-1976, abordando filmes do Centro Português de Cinema, subvencionados pela Fundação Gulbenkian, mas contemplando também filmes censurados que obtiveram outras formas de apoio financeiro. Nesta minha apresentação não procuro apontar qualquer tipo de evolução ou de maturação. Com ela pretendo apenas facilitar a percepção de algumas tendências que se tornaram cada vez mais marcantes enquanto o Novo Cinema se aproximava do 25 de Abril, e que talvez possam ser vistas como reflexo da crescente insatisfação com a ditadura, como resultado da rejeição da Guerra Colonial (1961-1974), e como consequência da repressão política. Para tal, voltarei agora também à minha questão inicial sobre o horizonte de esperança no sentido blochiano.

\section{1-1966}

Começo com os três longas-metragens que inauguraram o Novo Cinema. Ambas de 1962, as duas primeiras produções foram realizadas fora do âmbito da Cunha Telles: a já mencionada produção coletiva, Dom Roberto, de José Ernesto de Sousa, e um dos filmes mais polêmicos da história do cinema português, Acto da primavera, subsidiado pelo Fundo de Cinema e realizado por uma figura com um filmografia pequena, mas já com status de mito, Manoel de Oliveira. O terceiro filme é Os verdes anos, de Paulo Rocha, de 1963, planejado de forma independente, mas que acabou sendo integrado ao grupo de Cunha Telles. Estes três filmes possuem propostas bem diferentes: Dom Roberto e Acto da primavera são marcados por uma perspectiva otimista e confiante, de forma convencional no primeiro e por meio de uma estética 
Ferreira

arrojada no segundo, enquanto Os verdes anos enfrenta o espectador com uma situação de empate que resulta num ato de violência cuja força transformadora não é imediata, pelo menos quando se ignora o seu potencial estético.

\section{Dom Roberto}

Anunciado como "cinema novo" e "filme novo," Dom Roberto, a despeito das circunstâncias de produção coletiva, decepcionou. Foi acusado por muitos de não ter cumprido sua promessa de ir além da proposta neorrealista associada ao realizador Manuel Guimarães (Pina; Costa; Monteiro). O filme conta a história de um fantocheiro miserável que oferece o seu último dinheiro a uma jovem mulher que encontra à beira do suicídio. Sem meios para se sustentar, começam a morar numa casa abandonada, onde o fantocheiro inventa um lar para os dois, até o espaço ser destruído para dar lugar a um prédio moderno.

O filme mostra como o protagonista marginalizado consegue projetar um horizonte de esperança para ele e para a amada, um oásis de ternura num mundo pouco acolhedor. Se o filme peca pela falta de realismo, no sentido de que não oferece detalhes que possam tornar a situação desses desfavorecidos credível, ele encanta através da inventividade, da humanidade e da imaginação de seus personagens. Presente também no modo de produção do filme, a força de vontade deles faz esquecer a simplicidade da mise-en-scène e das falhas do roteiro. O que permanece após o visionamento é aquilo que Eduardo Prado Coelho chamou de "humanismo da imaginação," uma lição que Sousa herdou do neorrealismo e que possui um potencial político, pois implica que "o homem imagina, e portanto existe, e portanto é capaz de se revoltar" (16). Prado Coelho vai assim além da leitura habitual, pois assinala uma dimensão de esperança.

\section{Acto da primavera}

Acto da primavera (1961-1962), de Manoel de Oliveira, é sempre mencionado no contexto do Novo Cinema. Contudo, devido ao debate acerca do seu gênero (se é ou não um documentário), tal filme nunca foi visto como filme inaugural. $\mathrm{Eu}$ o defini como filme indisciplinar em escritos anteriores, embora não deva ser compreendido como rutura, senão como continuação de uma busca anterior do realizador. No entanto, quando se fala em Novo Cinema, ele deve constar 
como um dos filmes mais importantes. Henrique Alves Costa reconheceu desde cedo a dimensão estético-política do filme. Pensando numa lógica historiográfica, aponta-o como primeiro filme político português "em que Manoel de Oliveira ousava dizer, por subtis linhas travessas, o que ninguém, entre nós, ousara dizer por linhas tortas ou direitas" (42).

Acto da primavera reinterpreta a representação de um auto medieval, $A$ Paixão de Cristo de Francisco Vaz de Guimarães, realizado anualmente por amadores em Chaves, Trás-os-Montes, no interior de Portugal. Reflete sobre a condição humana contemporânea e a representação do sagrado por meio da relação entre a apresentação teatral e a sua representação cinematográfica. Subvencionado pelo Fundo de Cinema, foi o retorno de Oliveira à produção no formato de longa-metragem (depois dos importantes curtas-metragens indisciplinares $O$ pintor e a cidade, de 1956, e O pão, de 1959), do qual tinha ficado afastado durante 21 anos por falta de apoios financeiros. Devido à temática religiosa, muitos críticos acusaram Oliveira de conservadorismo católico (Costa). Entretanto, é de fato uma obra-prima que introduz na cinematografia portuguesa a investigação da ligação entre estética e política, mormente através de conflitos bélicos do século passado, estabelecendo assim uma associação entre esses conflitos e a Guerra Colonial na África, que tinha acabado de começar. Provavelmente por motivos de censura e autocensura, essa ligação nunca foi pronunciada na crítica.

A incidência de modernidade e tradição, de sacrilégio e sagrado fecha o filme. Após imagens do sepulcro de Cristo, Oliveira mostra em vez da ressurreição uma colagem de imagens dos horrores das guerras do século passado decorrentes da tecnologia militar, sendo a primeira imagem a queda da bomba atômica. Ao longo da colagem, imagens da figura de Cristo são intercaladas com o sofrimento de vítimas de guerras contemporâneas na Indochina. O que mais me interessa aqui é o fato de que, apesar das atrocidades, Oliveira apresenta no último plano uma árvore primaveral em flor, o "Princípio esperança" para toda a humanidade através de simbologia indubitavelmente cristã. Na perspetiva do cineasta, essa esperança está preservada não só no texto do auto, mas sobretudo no povo português do interior. Os verdadeiros tesouros que se encontram escondidos no Portugal profundo e na representação do auto são a capacidade de esperar e a possibilidade de realização da esperança pelo coletivo. Revelá-los acaba sendo o papel do cineasta contemporâneo. 
Ferreira

\section{Os verdes anos}

Filme recebido como rutura definitiva com o cinema do passado, Os verdes anos (1963) teve o seu financiamento recusado pelo Fundo de Cinema. Dessa forma, acabou sendo o primeiro longa-metragem da produtora Cunha Telles. Premiado em 1964 com a Vela de prata no Festival de Locarno, o filme narra a história do amor frustrado de dois jovens vindos do interior. De fato, na direção de Paulo Rocha, o meio rural sofre uma reinterpretação que mostra o outro lado da esperança oliveiriana.

Quando Júlio, que tenta sua sorte em Lisboa como sapateiro, conhece Ilda, uma jovem empregada doméstica, ela recusa o seu pedido de casamento. Incapaz de lidar com a rejeição por se sentir desamparado na cidade moderna, ele reage de forma radical e surpreendente, assassinando-a. Esse ato de Júlio não surge de um conflito geracional ou de uma oposição ao velho ou à sociedade que o explora, como poderiam indicar tanto sua relação com o tio com quem mora, quanto a relação com o seu patrão, um sapateiro que o acusa de ser preguiçoso mas que o faz trabalhar aos domingos. Tal ato resulta, sobretudo, das contradições geridas pela inacessibilidade aos bens de consumo do mundo moderno, bens tais que nunca poderiam ser adquiridos com o pequeno rendimento do jovem de classe social baixa.

Ilda é uma personagem ambígua nesse contexto: sonha com ascensão social e uma vida melhor. A reflexão sobre a modernidade em Os verdes anos é acima de tudo a expressão da consciência das contradições que ela torna ainda mais visíveis. Deriva, por um lado, das diferenças de classe profundamente enraizadas na sociedade portuguesa e, por outro, dos valores conservadores e pequeno-burgueses de todas as personagens masculinos - também daqueles que vêm da província, inclusive Júlio.

Há muitas afinidades com a Nouvelle Vague francesa, no sentido da importância da mise-en-scène: muitas vezes os espaços onde as personagens deambulam são fechados pela arquitetura moderna; e as delimitações dos pequenos espaços aos quais os trabalhadores são restringidos-por exemplo, a cozinha de Ilda e a pequena oficina de sapataria, da qual se avista a rua por uma janela muito baixa — são realçadas através do enquadramento. O final do filme é 
certamente a parte mais ousada, principalmente através da montagem que desorienta o espectador por meio de jump cuts.

Após matar Ilda, Júlio entra num café e olha para os fregueses como se quisesse desafiá-los, e eles retornam o olhar atônitos. Não existe só um culpado nesse confronto de olhares. Para acentuar essa ideia, Júlio primeiro esfrega sua mão cheia de sangue num garçom e depois corre para a rua, onde é cercado por diversos carros. Planos de detalhes dos carros, planos filmados de dentro deles e planos plongés que se afastam cada vez mais são montados num ritmo agitado e sem respeitar as regras da montagem contínua, sugerindo a maneira pela qual Júlio é alambrado pela modernidade. A esperança parece ausente nesse filme sobre o isolamento e o desamparo das personagens. Poder-se-ia dizer, porém, que ela se manifesta na estética que questiona o consenso sobre a hegemonia da sociedade classista e opressiva portuguesa, que coloca os seus jovens em situações sem saída.

\section{Produções Cunha Telles}

É possível verificar nas produções dos anos seguintes a mesma multiplicidade de perspetivas e estilos dos primeiros três filmes do cinema novo: há dois trabalhos próximos do neorrealismo-O crime da aldeia Velha, de 1964, e O trigo e o joio, de 1965, ambos de Manuel Guimarães, sendo o primeiro uma produção Cunha Telles - e três filmes que procuram uma estética própriaDomingo à tarde, de António de Macedo, As ilhas encantadas, de Carlos Villardebó, ambos de 1965, e Mudar de vida, de 1966, segundo longa de Paulo Rocha; todos são produções Cunha Telles. Para refletir sobre os valores das comunidades sobre as quais se debruçam, seja de pescadores, seja de médicos, seja de aldeões, a dimensão metafísica torna-se uma preocupação importante em boa parte desses filmes. A ausência ou o excesso de religiosidade é ponto de partida para repensar a falta de valores humanistas ou indício do impedimento da concretização de vidas conduzidas pela vontade própria. Dois protagonistas dos cinco filmes vivem transformações que indicam que as esperanças de um mundo melhor - atingido ora pela solidariedade, ora pela emigração-podem se tornar realidade.

Encontramos duas visões quase opostas sobre a vida rural nos dois filmes de Manuel Guimarães. O crime da aldeia Velha se baseia num caso verídico do 
Ferreira

século XIX e conta a história de uma mulher bonita que é hostilizada pela comunidade retrógrada da aldeia Velha, porque sua beleza é considerada demoníaca. No desfecho, é queimada na fogueira, num ato obviamente infame e cruel.

As personagens de $O$ trigo e o joio, por outro lado, abandonam certas superstições e transformam suas vidas miseráveis no Alentejo ao substituir velhas crenças por perspetivas mais concretas: o trabalho coletivo e a solidariedade. Embora as difíceis condições de vida sejam retratadas sem romantismos, há espaço para esperança no final. A narrativa gira em torno da compra de uma burra, que deve ser adquirida para ajudar no trabalho árduo de cultivar a terra. Quando é finalmente comprada, depois de muitos percalços e por um preço baixo, descobre-se que tem lepra. Para assegurar a saúde da filha, a esposa do camponês Loas decide matar a burra, contra a vontade do marido. Este último só se conforma quando o amigo Barbaças, um preguiçoso que vive à custa deles e que perdera por ingenuidade o dinheiro para comprar a burra no início, toma finalmente uma atitude e demonstra ao amigo que o caminho a seguir é o da força de vontade: ele pega no arado e começa a fazer o trabalho destinado ao animal.

Domingo à tarde, por sua vez, regressa ao meio urbano, onde o seu protagonista, um médico cético que trabalha no Instituto de Oncologia de um hospital lisboeta, é confrontado com a resignação e com a falta de humanismo perante a inevitável morte de seus pacientes. Quando se apaixona por uma delas, a consciência da vida, dos limites da ciência, e da dimensão metafísica entram novamente no mundo asséptico e desumano da rotina hospitalar onde a tecnologia dominara os relacionamentos humanos. Através de planos plásticos e às vezes abstratos, o filme constrói um olhar diferente, que serve como aliado na recuperação da sensibilidade perdida do protagonista, visando recuperar também a do espectador.

Dos filmes da Produções Cunha Telles, apenas $O$ trigo e o joio e Mudar de vida demonstram um compromisso mais imediato com os problemas reais e políticos do país. Mas enquanto Manuel Guimarães aceita o paternalismo dos donos da terra e é complacente com malandros e corruptos, Paulo Rocha tem a ousadia de utilizar o pescador Adelino, uma personagem que regressa da Guerra Colonial para mostrar um mundo em plena transformação e que exige mudanças, seja na escolha da parceira, seja em relação ao rumo da sociedade. $\mathrm{O}$ 
protagonista acaba "votando com os pés" e opta por um futuro na emigração, libertando-se assim de um país cuja modernização não o contempla—caminho esse que Júlio em Os verdes anos não conseguia imaginar, mas que the era sugerido por Ilda.

\section{7-1976}

Paradoxalmente, apesar da "primavera marcelista" e de suas tímidas mudanças políticas, e no contexto de novas possibilidades de produção conquistadas pelos cineastas através do CPC, a esperança de uma reestruturação justa da sociedade portuguesa parece diminuir nas produções financiadas pela Fundação Gulbenkian - e não só, embora o crescente pessimismo muitas vezes seja expresso de forma ambígua. N'O cerco (1969), de António Cunha Telles, esse fato pode ser notado claramente através da personagem principal feminina, que evidencia a emancipação da mulher do seu papel secundário, mesmo que isso significasse sacrifícios. Mas o filme também deixa claro que, do ponto de vista social, tal personagem permanece um objeto sem possibilidades efetivas de reinterpretar o seu papel de maneira concreta.

A relação entre os mecanismos opressivos da sociedade patriarcal e o autoritarismo da ditadura surgem com maior nitidez. A centralidade de personagens femininas reflete esse interesse. Notam-se referências mais explícitas à realidade política do país e a acontecimentos históricos. Citada uma única vez nos filmes analisados acima, O cerco (1969) aborda a Guerra Colonial com maior frequência, mesmo que o faça apenas três vezes. Apesar disso há somente um filme que invoca a repressão política do Estado Novo de forma reconhecível em sua trama: O recado (1971), de Fonseca e Costa, em que agentes da Pide (Polícia Internacional e de Defesa do Estado) matam um jovem oposicionista no final.

O mal-estar generalizado e a falta de perspetiva dos jovens numa sociedade prepotente e corrupta manifestam-se não só em filmes situados no meio urbano até o 25 de Abril, nos já mencionados $O$ cerco e $O$ recado, mas também em Perdido por cem (1972), de António-Pedro Vasconcelos, em Sofia e a educação sexual (1974), de Eduardo Geada, e em Cartas na mesa (1973), de Rogério Ceitil, e ainda em Meus amigos (1974), de António Cunha Telles, e no filme O mal amado (1974), de Fernando Matos Silva-em grande maioria 
Ferreira

produções sob a chancela do CPC. Inaugurado em Os verdes anos, o deambular das personagens torna-se uma constante nesses filmes, seja pela cidade de Lisboa ou, no caso da Educação sexual, por Sintra. Apenas motivadas por desejos vagos de rebeldia, de mudança, ou por insatisfação, as andanças sem rumo ou objetivo concreto são capturadas com câmeras na mão e em narrativas elípticas, ou seja, com agilidade.

\section{Salve-se quem puder}

O "Princípio esperança" parece ausente ou suspenso nesses filmes, como se estivesse hibernando até que os tempos melhorassem. Sobrevive apenas como salvação individual que fecha os olhos à realidade sociopolítica. Como nos primeiros filmes do Novo Cinema, assistimos a diversas mortes de protagonistas e personagens secundárias, mas o número aumenta significativamente. Contudo, os desfechos não são apenas de desesperança: quase sempre ficam abertos ou são ambíguos.

Há vários exemplos emblemáticos disso. Protagonista de $O$ cerco, Marta não consegue libertar-se dos diversos assédios. Parece ser dona do próprio nariz, pois se separa do marido de quem se cansou e consegue manter-se como modelo e "aeromoça de terra." Jovem e bonita (sua fotogenia é explorada constantemente pela câmera), acaba sofrendo de uma forma ou de outra nas mãos dos homens com quem convive: do patrão na agência de publicidade, que lhe dá trabalho como modelo; do namorado estrangeiro, que é casado. Tem ainda um caso com um contrabandista ao qual recorre para melhorar a sua situação. Quando ele morre, sente-se culpada. Mesmo assim, ela segue sempre em frente, embora fique evidente que está infeliz e que o preço pago pela sobrevivência como mulher "independente" é alto.

Protagonista de $O$ recado, Lúcia enfrenta dificuldades e incertezas parecidas, a despeito da sua situação econômica aparentemente mais privilegiada. Seu amante Francisco regressa de uma longa estadia no exterior, mas eles se desencontram após ela ter recebido o recado dele. Na verdade, ele foi morto, insinua-se que por questões políticas. Após esse desencontro, que lhe oferecera a expectativa de voltar ao seu passado politizado e de rebeldia, ela decide enterrar suas ilusões e opta por uma vida confortável na alta sociedade, à 
qual sempre pertenceu. Mas essa opção desiludida é encenada como uma automutilação no desfecho.

$O$ recado possui de fato dois finais. O primeiro mostra o fechamento do ciclo "politizado" da protagonista, pois ela destrói e queima tudo o que expressava a sua resistência à burguesia. Não obstante, esse gesto demonstra que a velha rebeldia não acabou. No segundo final, o amigo filósofo do seu exnamorado oposicionista, que traz o nome simbólico de Maldevivre e habita numa praia de pescadores, compartilha o seu pão com um velho. No início do filme, o velho fizera um discurso, afirmando que tudo estava bem para quem tinha saúde. O companheirismo entre o intelectual e o representante do povo indica a existência de um mundo paralelo à burguesia. Um mundo simples, verdadeiro e o único que inspira a esperança de que essa aliança poderia mudar a sociedade algum dia, pois a burguesia é ou perseguida quando luta ou perdeu o interesse.

Perdido por cem é outro exemplo de salvação individual e lembra filmes anteriores, como Mudar de vida. Um jovem da província, Artur tenta construir uma vida nova em Lisboa. Trabalha com publicidade e com rádio, mas apenas esporadicamente. Joana, uma mulher mais velha, se apaixona por ele, e os dois planejam deixar o país para ter uma vida melhor. Pouco antes de embarcar, ela é assassinada no aeroporto pelo ex-namorado, que acabou de regressar da Guerra Colonial em Angola. O trauma da guerra e a violência que ela gera são facilmente percebíveis como resultado da coação da ditadura. Ameaçado por um destino semelhante ao do ex-namorado de Joana, Artur nega conhecê-la quando a polícia o interroga e parte para Roma. Melhor seguir em frente e cumprir o seu próprio desejo do que permanecer num lugar que não hesita em sacrificar seus jovens numa guerra sem sentido.

\section{Vítimas}

Fugir parece ser a única forma de escapar à morte certa. À Sofia, a protagonista que recebe a educação sexual no filme com o mesmo título, não se coloca a oportunidade de fugir da vida opressora da alta sociedade na qual vive. Suicidase, vítima da hipocrisia e do egoísmo do seu pai. O mal amado, por outro lado, é assassinado por sua chefe, que não admite o fim do relacionamento amoroso que mantiveram. A escolha de uma parceira mais nova e que lhe oferece um 
Ferreira

horizonte mais feliz, longe das exigências autoritárias da amante, é assim negada a esse jovem pela mão de uma mulher castradora.

Apesar do oportunismo, da corrupção e da hipocrisia da burguesia urbana, quase sempre associados a profissionais da publicidade que dificultam a vida desses jovens ou acabam com ela, a religião não sai de cena como preocupação de alguns cineastas, como a superstição que atrapalha a vida de um jovem casal em A promessa (1972), de António de Macedo. Para salvar a vida do pai, um pescador, José e sua noiva Maria do Mar (alusão religiosa óbvia) fazem um voto de castidade e não ousam quebrá-lo depois de casados. Quando o obscurantismo da religiosidade popular é finalmente transformado num ato de amor carnal, esse tem consequências fatais. Mesmo assim, o filme não deixa de apontar para um futuro mais promissor e mais humano.

Manoel de Oliveira também debate a dimensão religiosa em dois filmes para comentar o autoritarismo da sociedade portuguesa. Ele o faz primeiro em relação ao contexto urbano, em O passado e o presente (1971), ao examinar a institucionalização do casamento e seus efeitos malignos. A perversão e os paradoxos que ele gera na protagonista Vanda e na sociedade que a rodeia se refletem nos olhares elucidativos dos criados. Vanda só consegue amar seus maridos quando mortos - uma forma sinistra de escapar ao patriarcado. $\mathrm{O}$ amor livre de convenções sociais entre duas personagens secundárias surge como possível alternativa e uma vida mais promissora fora do alcance opressor das convenções sociais.

Já após o 25 de Abril o diretor retoma a sua inquietação com a falta de fé verdadeira em Benilde ou a virgem mãe (1975) no meio rural, adaptação da peça homônima de José Régio, que se traduz em falta de esperança e resulta em mais uma morte - desta vez, da protagonista, Benilde. Não resta dúvida de que a jovem grávida, que jura não ter tido relações sexuais, é mais uma vítima da sociedade tirânica e vazia de valores, mas sempre prestes a esmagar o amor quando não serve a seus interesses dinásticos.

\section{Filmes censurados}

Não obstante a "primavera marcelista," quando mais perto chegamos do 25 de Abril, maiores se tornam a vigilância por parte da censura e o desafio que isso coloca aos cineastas. Enquanto na primeira fase do Novo Cinema, Catembe 
(1965), de Faria de Almeida, foi proibido de estrear mesmo tendo sido mutilado pela censura, quatro filmes são agora banidos: Grande, grande era a cidade (1971), de Lauro António e Rogério Ceitil, Deixem-me ao menos subir às palmeiras (1972), de Lopes Barbosa, o já mencionado Sofia e a educação sexual (1973) e Índia (1973), de António Faria. Dois desses filmes lidam de forma crítica com o passado e o presente do colonialismo português, enquanto os outros dois retratam mais abertamente as mazelas da burguesia.

É curioso notar que os dois filmes mais alegóricos e políticos, Brandos costumes, de Alberto Seixas Santos, realizado entre 1973 e 1975, e Os demónios de Álcacer-Kibir, de Fonseca e Costa, produzido em 1975 e estreado em 1977, ambos projetos do CPC, só chegaram aos cinemas quando o processo de redemocratização do país já tinha se iniciado. Brandos costumes é particularmente interessante, pois o filme guarda certo ceticismo em relação a possíveis mudanças da sociedade portuguesa pós- 25 de Abril, mesmo com o passado marxista do seu diretor. Sugere que, por sua longa convivência com a tirania, a oposição não possui nenhum projeto para o futuro, ou seja, apresenta exatamente a desesperança encontrada por Pina, Costa e Monteiro, citados acima. O filme de Fonseca e Costa é igualmente pessimista sobre o destino de Portugal, mas encontra para a personagem que representa a África uma perspetiva esperançosa.

\section{Arte do medo e da esperança}

Para fechar minha abordagem dos filmes da assim chamada segunda fase do Novo Cinema, gostaria de realçar a singularidade de Uma abelha na chuva, adaptação do romance neorrealista homônimo de Carlos de Oliveira pelo cineasta Fernando Lopes, cujo processo de realização se estendeu de 1968 a 1971. O filme conta como o relacionamento doentio de um casal de abastados lavradores, Álvaro e Prazeres, é responsável por mais mortes - desta vez, de um jovem casal de empregados na propriedade dessa elite da Comarca (Ferreira).

Mas enquanto a perpetuação do poder da alta burguesia rural é temática principal do romance em que se baseia, o filme demonstra uma perspetiva mais promissora em seu final. Ela se manifesta nas descontinuidades entre som e imagem que servem tanto como equivalências ao estilo do romance, como para a criação de uma estética própria, que se constrói através de planos demorados 
Ferreira

e contemplativos de fragmentos da residência deserta do casal latifundiário; de travellings morosos sobre suas propriedades esvaziadas; da montagem repetitiva, que quebra o fluxo da narrativa em conjunto com freeze frames ou inserts de fotografias; e do uso da montagem horizontal, que em vez de reproduzir os sons e os diálogos diegéticos descarta o som sincronizado com a imagem por meio da montagem de sons extradiegéticos.

Indo além da reafirmação crítica da decadência da burguesia agrícola trabalhada no romance, o filme afirma em seu desfecho a existência de uma resistência estética e assume a capacidade de questionar a identidade hegemônica pelos meios do cinema. Há, portanto, uma ambiguidade: a narrativa demonstra a erradicação de qualquer "Princípio esperança," enquanto a estética encontra meios - os planos e a montagem - para formular o seu dissenso sobre a hegemonia que representa a desesperança, lembrando a distopia de Os verdes anos.

\section{Conclusão}

Ao contrário do que se costuma dizer em relação ao Novo Cinema, é possível afirmar que os filmes dos primeiros anos ensaiam o reaprendizado da esperança de diversas maneiras. Em Dom Roberto através da "imaginação humanista" dos marginalizados, em Acto da primavera recordando-se a utopia humanista e cristã que sobreviveu numa aldeia no interior português, em Domingo à tarde recuperando-se a sensibilidade através da confrontação com o amor e com a morte, ou ainda em $O$ trigo e o joio através da solidariedade dos trabalhadores. Em um momento de pouca perspetiva, dado o início da Guerra Colonial, que procurava eternizar o império português ao mesmo tempo em que a descolonização se espalhava pelo continente africano, e logo após as falhadas tentativas de afastar Salazar do poder-, este balanço não parece nada mal. O reaprendizado da esperança coexiste com a visão pessimista de Os verdes anos, que delega a expectativa de mudança para a estética ao passo que traduz em planos metafóricos o beco sem saída do seu jovem protagonista. Este aprendizado convive também com o desejo de abandonar o país, desejo realizado em Mudar de vida. Ambos os filmes de Paulo Rocha partem do princípio de que a reestruturação da sociedade portuguesa em andamento só 
beneficia a burguesia, e por isso é preciso partir para outras bandas, onde a vida promete ser melhor.

Ao contrário do que se poderia pensar, o "Princípio esperança" quase sai de cena quando o ditador Oliveira Salazar abandona o palco político. Projetos utópicos que poderiam tornar-se realidade através de um esforço coletivo não se encontram com facilidade na segunda metade da década de 60 e nos primeiros anos da década de 70. O cerco, O recado e Perdido por cem possuem protagonistas que se agarram à própria sobrevivência, embora fique claro que seus projetos individuais sejam ambíguos e pouco satisfatórios. Aumenta o número de vítimas dos valores conservadores veiculados pela sociedade autoritária e apoiados em certos dogmas da Igreja Católica: jovens mulheres e homens se suicidam, são assassinados ou morrem de desgosto em Sofia e a educação sexual, O mal amado e em Benilde ou a virgem mãe. Outras vidas são afetadas de forma negativa, tornando as pessoas obsessivas e perversas, como ocorre em O passado e o presente e em A promessa. Quando os protagonistas não acabam como vítimas, seus diretores são vitimizados, pois a censura impossibilita ou atrasa a estreia de um número significativo de filmes (Grande, grande era a cidade, Deixem-me ao menos subir às palmeiras, Sofia e a educação sexual e Índia). No entanto, o horizonte de esperança não se perde e sobrevive ou na resistência de figuras isoladas (O cerco, O recado e Perdido por cem), através de protagonistas (A promessa) e personagens secundárias $(O$ passado e o presente), ou por meio do dissenso estético, nomeadamente em Uma abelha na chuva, O passado e o presente e Benilde ou a virgem mãe.

Com base nessas análises, parece-me possível afirmar que a ideia frequentemente veiculada pelas historiografias do cinema português de que os filmes do Novo Cinema realizados entre 1961 e 1978 são sobretudo fatalistas e pouco políticos deve ser revista. A reestruturação imediata da sociedade decerto não aparece no horizonte de nenhum, e os cineastas se socorrem na análise e na demonstração dos mecanismos da arte de temer. De fato, a opressão é retratada como uma força destruidora, profundamente enraizada numa sociedade que perpetua valores castradores, vazios e fatais. De qualquer forma, é possível interpretar de outra forma os filmes de teor mais desesperado, com mortes causadas pelo autoritarismo e pelo machismo. Suicídios, assassinatos e outras fatalidades indicam sem dúvida o quanto o autoritarismo da ditadura foi vigoroso. Parece-me, contudo, que todos esses casos podem ser pensados no 
contexto da base cultural portuguesa, invocada por Manoel de Oliveira no primeiro longa do Novo Cinema de forma consciente e inconfundível. A figura principal do "Princípio esperança," o Salvador, entra "em cena" através da representação no auto. Sendo assim, as mortes das personagens podem ser lidas também como sacrifícios, sacrifícios substitutos para que a sociedade possa alcançar um mundo melhor. De alguma forma são todos suplentes que morrem com base na utopia cristã da ressurreição.

Embora os projetos nos primeiros anos da década de 60 sejam vagos (o humanismo cristão de Acto da primavera), simples (a solidariedade em $O$ trigo e o joio), românticos (um lar imaginário em Dom Roberto) ou, nos filmes do final da época, sobretudo projetos individuais, estes últimos também podem ser entendidos como concessões a aspirações maiores. Há sonhos dos quais as personagens se afastam ou que são esmagados porque assinalam o potencial de alternativas. Exemplos são o projeto político em $O$ recado, a vida numa sociedade livre em Os verdes anos, Mudar de vida e Perdido por cem, e o amor livre das convenções sociais em $O$ passado e o presente.

Ao entender a conexão entre estética e política como o faz Jacques Rancière, entendimento que significa uma postura que vá além das propostas modernistas ou pós-modernistas ao ver o político como sendo parte inseparável do estético-isto é, da reconfiguração na arte da partilha do sensível一é possível perceber como o Novo Cinema parte para a modificação do status quo dessa partilha que define a distribuição dos lugares e dos papéis em uma sociedade, principalmente por meio de seus recursos cinematográficos:

Existe portanto, na base da política, uma 'estética' ... [que é] um recorte dos tempos e dos espaços, do visível e do invisível, da palavra e do ruído que define ao mesmo tempo o lugar e o que está em jogo na política como forma de experiência. A política ocupa-se do que se vê e do que se pode dizer sobre o que é visto, de quem tem competência para ver e qualidade para dizer, das propriedades do espaço e dos possíveis do tempo. (Rancière 16-17)

O exemplo que melhor demonstra o anseio de recortar a realidade de uma maneira que permita pensar e aprender a esperar é, como já afirmei, Uma abelha na chuva. Mas filmes como Os verdes anos, Domingo à tarde, O 
passado e o presente e Benilde ou a virgem mãe também podem ser nomeados nesse contexto, entre vários outros que participam da reconfiguração do sensorium espaço-temporal. Refletem a confiança de que os dias da ditadura estão contados e de que o desejo desse fim pode tornar-se realidade.

Bloch termina $O$ Princípio esperança com a observação de que "os homens, assim como o mundo, carregam dentro de si a quantidade suficiente de futuro; nenhum plano é propriamente bom se não contiver essa fé basilar" (433). No Novo Cinema português há poucos protagonistas que compartilham essa certeza, e nem sempre conseguem vivê-la mesmo quando a possuem. É correto que não haja propostas concretas e que se demonstre constantemente que os menores desejos podem terminar com a morte. A conclusão disso não é necessariamente de que se trate de filmes fatalistas ou pouco políticos. Perante a impossibilidade de realizar utopias numa sociedade totalitária, os realizadores não desistiram da busca de caminhos político-estéticos que pudessem modificar a perceção dela e, com isso, alertar para a necessidade de uma mudança da partilha do sensível, ou seja, da distribuição dos lugares e dos papéis naquele momento histórico. Nisso consiste sua tentativa de nos fazer aprender a esperança.

\section{Obras citadas}

Almeida, Faria de, realizador. Catembe. Fundo do Cinema Nacional, 1965.

Barbosa, Lopes, realizador. Deixem-me ao menos subir às palmeiras. Fundo do Cinema Nacional, 1972.

Bloch, Ernst. O princípio esperança, traduzido por Nélio Schneider e Werner Fucks, Contraponto, 2005.

Ceitil, Rogério, realizador. Cartas na mesa. Centro Português de Cinema, 1973.

-, e Lauro António, realizadores. Grande, grande era a cidade. Centro Português de Cinema, 1971.

Coelho, Eduardo Prado. Vinte anos de cinema português. Biblioteca Breve, 1983.

Costa, João Bénard da. História(s) do cinema. Imprensa Nacional-Casa da Moeda, 1991.

Cruchinho, Fausto. "Os passados e os futuros do Cinema Novo: o cinema na polémica do tempo." Estudos do Século XX, no. 1, 2001, pp. 215-40. 
Ferreira

Cunha Telles, António da, realizador. Meus amigos. Centro Português de Cinema, 1974.

-. O cerco. Cinenovo Filmes, 1970.

Faria, António, realizador. Índia. Centro Português de Cinema, 1973.

Ferreira, Carolin Overhoff. O cinema português: aproximações a sua história e indisciplinaridade. Alameda, 2015.

—. "Os Verdes Anos." O cinema português através dos seus filmes, editado por Carolin Overhoff Ferreria, Edições 70, 2014, pp. 103-12.

Fonseca e Costa, José, realizador. Os demónios de Álcacer-Kibir. Centro Português de Cinema, 1977.

—. O recado. Centro Português de Cinema, 1971.

Geada, Eduardo, realizador. Sofia e a educação sexual. Doperfilme, 1974.

Guimarães, Manuel, realizador. O crime da aldeia Velha. Produções Cunha Telles, 1964.

—. O trigo e o joio. Produções Cunha Telles, 1965.

Lopes, Fernando, realizador. Belarmino. Produções Cunha Telles, 1964.

—. Uma abelha na chuva. Media Filmes, 1971.

Macedo, António de, realizador. A promessa. Centro Português de Cinema, 1972.

—. Domingo à tarde. Produções Cunha Telles, 1965.

Matos-Cruz, José de. Prontuário do cinema português: 1896-1989. Cinemateca Portuguesa, 1989.

Matos Silva, Fernando, realizador. O mal amado. Centro Português de Cinema, 1974.

Monteiro, Paulo Filipe. "Uma margem no centro: a arte e o poder do novo cinema." O cinema sob o olhar de Salazar, editado por Luís Reis Torgal, Círculo de Leitores, 2000, pp. 306-38.

Oliveira, Manoel de, realizador. Acto de primavera. Manoel de Oliveira, 1962.

—. Benilde ou a virgem mãe. Centro Português de Cinema, 1975.

—. O pão. Federação Nacional dos Produtores de Trigo, 1959.

—. O passado e o presente. Centro Português de Cinema, 1971.

-. O pintor e a cidade. Manoel de Oliveira, 1956.

Pina, Luís de. História do cinema português. Europa-América, 1986.

Pires, José Cardoso. E agora, José? Dom Quixote, 1999. 
Rancière, Jacques. A partilha do sensível: estética e política, traduzido por Mônica Costa Netto, Editora 34, 2009.

Rocha, Paulo, realizador. Mudar de vida. Produções Cunha Telles, 1965.

-. Os verdes anos. Produções Cunha Telles, 1963.

Santos, Alberto Seixas, realizador. Brandos costumes. Centro Português de Cinema, 1975.

Souza, Ernesto de, realizador. Dom Roberto. Cooperativa do Espectador, 1962.

Tropa, Alfredo, realizador. Pedro só. Centro Português de Cinema, 1971.

Vasconcelos, António-Pedro, realizador. Perdido por cem. Centro Português de Cinema, 1972.

Vieira, Antonio Rufino. "Princípio esperança e a herança intacta do marxismo em Ernst Bloch." Anais do V colóquio internacional Marx-Engels, U de Campinas, 2007. www.unicamp.br/cemarx/anais_v_ coloquio_arquivos/ arquivos/comunicacoes/gt1/sessao6/Antonio_Rufino.pdf. Acesso em $10 \mathrm{de}$ outubro 2009.

Vilardebó, Carlos, realizador. As ilhas encantadas. Produções Cunha Telles, 1965. 